\title{
How to Construe Section 1782: A Textual Prescription to Restore the Judge's Discretion
}

\author{
Steven M. Saraisky†
}

Parties and courts involved in international litigation must often seek evidence located in a foreign country. For foreigners attempting to gather evidence located in the United States, treaties and statutory provisions prescribe various methods to carry out the search. ${ }^{1} 28$ USC $\S 1782$, one of these procedures, gives foreigners a direct and effective route to legal assistance from United States courts. Section 1782 allows a district court judge to order a person in the district to give testimony or produce documents or other things for use in a foreign proceeding. ${ }^{2}$

Section 1782 is effective primarily because it does not impose strict, formalistic requirements on foreign requests for assistance. Whereas other procedures require forwarding through (often complex) diplomatic channels, ${ }^{3} \S 1782$ permits requests to be sent directly to the district court. ${ }^{4}$ While other procedures frequently require a detailed list of background information, ${ }^{5} \S 1782$

$\dagger$ A.B. 1990, Dartmouth College; J.D. Candidate 1994, The University of Chicago.

1 See, for example, Convention on the Taking of Evidence Abroad in Civil or Commercial Matters, [1972] 23 UST 2555, 2558, TIAS No 7444 (1970) ("Hague Convention"); Treaty Between the Government of the United States of America and the Government of the Republic of Argentina on Mutual Legal Assistance in Criminal Matters (1990) (on file with U Chi L Rev) ("Treaty for Mutual Assistance with Argentina"); Inter-American Convention on Letters Rogatory (1975), in Martindale-Hubbell International Law Digest IC-45 (1994).

228 USC $\S 1782$ (1988). The language of the statute is set out in note 9 and the accompanying text.

3 For example, requests for evidence under the Hague Convention and the Treaty for Mutual Assistance with Argentina must pass through a Central Authority designated by each signatory nation. See Hague Convention, 23 UST at 2558; Harvey M. Sklaver, Obtaining Evidence in International Litigation, 7 Cumb L Rev 233, 247 (1976); Treaty for Mutual Assistance with Argentina at § 2.

4 See 22 CFR $\S 92.67$ (d) (1993) (allowing the transmittal of a request by direct international mail or by a party, as well as by a consular officer or agent, or by the Department of State).

5 Requests for evidence under both the Hague Convention and Mutual Assistance treaties must recite several pro forma items. See Hague Convention, 23 UST at 2558-59; Treaty for Mutual Assistance with Argentina at $\$ 4$ (describing the form and content of requests). See also Sklaver, 7 Cumb L Rev at 247-48. 
imposes few formal requirements. ${ }^{6}$ The statute was designed to facilitate broad international judicial cooperation and to avoid the bureaucratic tedium that often hinders other international procedures. $^{7}$

The United States has not always provided such ready assistance. Although a statute allowing federal courts to lend assistance to foreign courts has existed for nearly 140 years, the scope of this assistance was fairly limited prior to $1964 .^{8}$ Amendments adopted in that year greatly expanded the reach of the statute. Unfortunately, these changes have also led courts to adopt unclear and conflicting legal standards.

First, courts have disagreed about whether the statute allows discovery in the United States of evidence that would not be discoverable in the foreign jurisdiction. Some courts have imposed limitations to prevent circumvention of foreign discovery rules, but in so doing have greatly restricted the statute's breadth. Second, courts have disagreed about whether foreign investigating officials, like prosecutors or tax officers, have standing to request assistance prior to commencement of adjudicative proceedings. Finally, courts have failed to settle on a uniform test for evaluating the merits of $\$ 1782$ requests in general.

Resolution of these issues is important for several reasons. Because $\S 1782$ allows a broad class of persons to request assistance and avoids bureaucratic complications, it is perhaps the most appealing means of obtaining evidence located in the United States. Furthermore, uniform application of the statute will encourage reciprocity by other countries. Finally, as the world economy grows more interrelated, an increasing number of international disputes will require the consistent and efficient disposition of $\$ 1782$ requests.

${ }^{6}$ See 22 CFR 92.67(b) (1993) ("A letter rogatory customarily states the nature of the judicial assistance sought by the originating court, prays that this assistance be extended, incorporates an undertaking of future reciprocity in like circumstances, and makes some provision for payment of fees and costs entailed in its execution."). Incidentally, a letter rogatory is "a request by a judicial authority to a foreign judicial authority, forwarded through the diplomatic channel, for the performance within the territory of the foreign country of some act necessary or ancillary to the litigation pending in the forum." Harry Leroy Jones, Letters Rogatory in Federal Practice, in Bernard A. Grossman, ed, Letters Rogatory 73 (Federal Legal Publications, 1956). See also The Signe, 37 F Supp 819, 820 (E D La 1941) ("Letters rogatory are the medium, in effect, whereby one country, speaking through one of its courts, requests another country, acting through its own courts and by methods of court procedure peculiar thereto and entirely within the latter's control, to assist the administration of justice in the former country .....).

7 See text accompanying notes $\mathbf{2 7 - 2 8}$.

8 See text accompanying notes 10-26. 
To remedy the present confusion over $\S 1782$, this Comment undertakes a textual analysis and proposes a return to the statute's plain language, which grants broad discretion to the district judge. Section I examines the language and legislative history of $\$ 1782$. Section II examines the different judicial interpretations of the statute. Section III criticizes the courts' approaches and offers a three-part test grounded in the plain language of the statute. A return to this textualist interpretation would not only resolve conflicting decisions and provide guidance for courts and parties alike, but would also best uphold the policies and values supporting the foreign letters rogatory statute.

\section{THE STATUTE}

As amended in 1964, 28 USC $\S 1782$ is entitled "Assistance to foreign and international tribunals and to litigants before such tribunals." It states in relevant part:

The district court of the district in which a person resides or is found may order him to give his testimony or statement or to produce a document or other thing for use in a proceeding in a foreign or international tribunal. The order may be made pursuant to a letter rogatory issued, or request made, by a foreign or international tribunal or upon the application of any interested person ....

The statute is comprised of a mix of discretionary and mandatory rules. Three of the statute's operative rules are discretionary. The district court may honor foreign requests for judicial assistance; the court may appoint a person to collect the evidence; and the court order may prescribe the practice and procedure to be followed. But any request for assistance must also

Subsection (a) continues:

[The order] may direct that the testimony or statement be given, or the document or other thing be produced, before a person appointed by the court. By virtue of his appointment, the person appointed has power to administer any necessary oath and take the testimony or statement. The order may prescribe the practice and procedure, which may be in whole or part the practice and procedure of the foreign country or the international tribunal, for taking the testimony or statement or producing the document or other thing. To the extent that the order does not prescribe otherwise, the testimony or statement shall be taken, and the document or other thing produced, in accordance with the Federal Rules of Civil Procedure.

A person may not be compelled to give his testimony or statement or to produce a document or other thing in violation of any legally applicable privilege. 
meet three mandatory requirements. The request must be "for use in a proceeding in a foreign or international tribunal"; it must come from a foreign or international tribunal or an interested person; and the order must not violate "any legally applicable privilege." Most of the controversy surrounding the application of $\S 1782$ stems from disputes over the proper interpretation of these mandatory rules.

\section{A. History}

Congress first authorized the federal courts to assist in gathering evidence for foreign courts in $1855 .^{10}$ The statute allowed an appointed commissioner to take testimony in the same manner as in federal court. ${ }^{11}$ However, the statute was generally unknown ${ }^{12}$ and faded into oblivion when Congress passed a new foreign assistance statute in $1863 .^{13}$ This enactment permitted assistance only in suits "[1] for the recovery of money or property [2] depending in any court in any foreign country with which the United States are at peace, and [3] in which the government of such foreign country shall be a party or shall have an interest . . . ."14 Restricted in this way, federal courts did not usually grant requests from foreign courts. ${ }^{15}$

\footnotetext{
10 See 10 Stat 630 , ch 140 \& (Mar 2, 1855).

1 The statute provided:
}

[W] here letters rogatory shall have [been] addressed, from any court of a foreign country to any circuit court of the United States, and a United States commissioner designated by said circuit court to make the examination of witnesses in said letters mentioned, said commissioner shall be empowered to compel the witnesses to appear and depose in the same manner as to appear and testify in court.

Id. Apparently, Congress passed the act because a year earlier the Attorney General and the State Department concluded that U.S. courts had no statutory authority to execute letters rogatory from a French official. See Harry L. Jones, International Judicial Assis. tance: Procedural Chaos and a Program for Reform, 62 Yale L J 515, 540 (1953).

12 The 1855 statute was catalogued under "Mistrials" in the Statutes at Large and was omitted for a time from the index to the federal code. See Jones, 62 Yale L J at 540 n 77. See also Walter B. Stahr, Discovery Under 28 U.S.C. \$ 1782 for Foreign and International Proceedings, 30 Va J Intl L 597, 601 n 18 (1990).

1312 Stat 769, 769-70, ch 95 (Mar 3, 1863). The Treasury Department was apparently unaware of the 1855 Act when it proposed the 1863 legislation. See Jones, 62 Yale L J at $540 \mathrm{n} 77$.

14 Stat at 769-70.

15 See, for example, Janssen $v$ Belding-Corticelli, Ltd, 84 F2d 577 (3d Cir 1936) (refusing to issue a subpoena duces tecum to compel a witness's testimony for Canadian litigation); In re Letters Rogatory from Examining Magistrate of Tribunal of Versailles, France, 26 F Supp 852 (D Md 1939) (refusing to order testimony for a foreign court's proceeding because the U.S. court's statutory authority was limited to civil cases involving money or property); In re Letters Rogatory from the First District Judge of Vera Cruz, $36 \mathrm{~F}$ 
With the growth of international litigation that followed World War II, ${ }^{16}$ the letters rogatory statute came under new scrutiny, and Congress amended it in $1948 .{ }^{17}$ These amendments eliminated the requirement that the foreign government be a party or have an interest in the case, and also expanded the statute to encompass "any civil action pending in any court in a foreign country."18 In 1949, Congress further broadened the statute to apply to "any judicial proceeding pending in any court in a foreign country."19

Although the 1948 and 1949 amendments allowed federal courts to provide additional assistance to foreign governments, critics still contended that the statute was ineffective. ${ }^{20}$ In 1958 , therefore, Congress created the Commission and Advisory Committee on International Rules of Judicial Procedure. ${ }^{21}$ The Commission was empowered to "investigate and study existing practices of judicial assistance and cooperation between the United States and foreign countries with a view to achieving improvements." ${ }^{\text {"22 }}$ The Commission sought to revise the law in order to provide "[w]ide judicial assistance... on a wholly unilateral basis." ${ }^{23}$ Working with the Columbia Law School Project on International Procedure, ${ }^{24}$ the Commission drafted and recommended amendments to the Federal Rules of Civil Procedure, amendments to sections of the United States Code, and for states, a

306 (S D NY 1888) (same).

${ }^{16}$ See Jones, 62 Yale L J at 558 (cited in note 11) ("At the end of hostilities, the surge of 'international' litigation again pointed up the critical inadequacy of our extraterritorial procedures."). See also Grossman, ed, Letters Rogatory at 50 (cited in note 6) (remarks of Samuel Miles Fink in group discussion noting that post-World War II growth in international commerce has been directly responsible for a marked increase in international litigation).

${ }_{17}$ Pub L No 80-773, 62 Stat 869, 949 (June 25, 1948).

18 Id.

19 Pub L No 81-72, 63 Stat 89, 103 (May 24, 1949).

${ }^{20}$ See, for example, Jones, Letters Rogatory in Federal Practice, in Grossman, ed, Letters Rogatory at 84-87 (criticizing then-existing American procedures for foreign letters rogatory); Jones, 62 Yale L J at 542 (same).

21 Pub L No 85-906, 72 Stat 1743 (Sept 2, 1958).

22 Id at $\$ 2$.

${ }^{23}$ Philip W. Amram, Public Law No. 88-619 of October 3, 1964 -New Developments in International Judicial Assistance in the United States of America, $32 \mathrm{~J}$ DC Bar Assn 24, 28 (1965).

24 Because Congress failed to appropriate funds for the Commission in 1959, the Commission sought private funding. Columbia Law School received a grant of $\$ 350,000$ from the Carnegie Corporation and used part of this grant to establish the Project on International Procedure. See Fourth Annual Report of the Commission on International Rules of Judicial Procedure, H Doc No 88, 88th Cong, 1st Sess 2 (1963) ("Fourth Annual Report"). 
Uniform Interstate and International Procedure Act. ${ }^{25}$ The amendments to the United States Code, including the amendments to $\S 1782$, passed Congress without objection in $1964 .^{26}$

\section{B. Legislative History of the 1964 Amendments}

The House and Senate Judiciary Committee reports accompanying the 1964 Amendments to $\S 1782$ focus on the liberalization of the statute ${ }^{27}$ and express the hope that other countries would follow the example of the United States. ${ }^{28}$ The reports concentrate on three aspects of the amended statute: its use of the word "tribunal," its understanding of who may be a requesting party, and its grant of broad discretion to the district court.

First, the committee reports indicate that "[t]he word 'tribunal' is used to make it clear that assistance is not confined to proceedings before conventional courts." ${ }^{29}$ For example, the court may grant assistance "when proceedings are pending before investigating magistrates." This is because "[i]n view of the constant growth of administrative and quasi-judicial proceedings at 7-8.

25 Amram, $32 \mathrm{~J} \mathrm{DC} \mathrm{Bar} \mathrm{Assn} \mathrm{at} 25$ (cited in note 23). See also Fourth Annual Report

${ }^{26}$ Pub L No 88-619, 78 Stat $995,997 \S 9$ (Oct 3, 1964). This amendment passed the House on January 20,1964 , on a voice vote without objection. See HR 9435, 88th Cong, 2d Sess, in 110 Cong Rec 596, 596-598 (Jan 20, 1964). It also passed the Senate on a voice vote without objection on September 24, 1964. See HR 9435, 88th Cong, 2d Sess, in 110 Cong Rec 22857 (Sept 24, 1964). See also Hans Smit, International Litigation Under the United States Code, 65 Colum L Rev 1015, 1017 (1965) (The bill passed "without encountering any objection in the Congress.").

${ }_{27}$ See Judicial Procedures-Litigation with International Aspects, S Rep No 88-1580, 88th Cong, 2d Sess (1964), reprinted in 1964 USCCAN 3782, 3788 (The revision of $\S 1782$ "clarifies and liberalizes existing U.S. procedures.").

${ }_{28}$ Judicial Procedures in Litigation with International Aspects, HR Rep No 88-1052, 88th Cong, 1st Sess 3 (1963). The Senate Report states:

Until recently, the United States has not engaged itself fully in efforts to improve practices of international cooperation in litigation. The steadily growing involvement of the United States in international intercourse and the resulting increase in litigation with international aspects have demonstrated the necessity for statutory improvements and other devices to facilitate the conduct of such litigation. Enactment of the bill into law will constitute a major step in bringing the United States to the forefront of nations adjusting their procedures to those of sister nations and thereby providing equitable and efficacious procedures for the benefit of tribunals and litigants involved in litigation with international aspects.

It is hoped that the initiative taken by the United States in improving its procedures will invite foreign countries similarly to adjust their procedures.

1964 USCCAN at 3783.

291964 USCCAN at 3788; HR Rep No 88-1052 at 9.

30 1964 USCCAN at 3788; HR Rep No 88-1052 at 9. 
all over the world, the necessity for obtaining evidence in the United States may be as impelling in proceedings before a foreign administrative tribunal or quasi-judicial agency as in proceedings before a conventional foreign court."31

Second, the committee reports describe the broad class of persons who may be requesting parties. The statute extends assistance "to international tribunals and litigants before such tribunals." Whereas the pre-1964 statute only permitted a grant of assistance in judicial proceedings pending in a court, the amended version of the statute allows foreign tribunals, international tribunals, litigants, and investigating magistrates to request assistance. By permitting U.S. courts to grant assistance to a much larger class of persons, the 1964 amendments significantly expanded the statute's breadth.

Finally, the committee reports explain that the district court judge has broad discretion to grant or deny a request. ${ }^{33}$ For example, "[i]n exercising its discretionary power, the court may take into account the nature and attitudes of the government of the country from which the request emanates and the character of the proceedings in that country, or in the case of proceedings before an international tribunal, the nature of the tribunal and the character of the proceedings before it."34 Thus lawmakers emphasized the discretion given to the district court judge and provided rudimentary guidelines for exercising that discretion.

\section{Commentary on the 1964 Amendments}

Soon after the enactment of the 1964 amendments, a number of commentators published explanatory articles about $\S 1782 .{ }^{35}$ Hans Smit's commentary is particularly relevant. Smit was a Professor of Law at Columbia Law School, Director of the Columbia Law School Project on International Procedure, and the Reporter to the Congressional Commission on International Rules of

31 1964 USCCAN at 3788; HR Rep No 88-1052 at 9 .

32 1964 USCCAN at 3788; HR Rep No 88-1052 at 9.

33 1964 USCCAN at 3788; HR Rep No 88-1052 at 9 ("[The statute] leaves the issuance of an appropriate order to the discretion of the court which, in proper cases, may refuse to issue an order or may impose conditions it deems desirable.").

34 1964 USCCAN at 3788; HR Rep No 88-1052 at 9.

35 See Smit, 65 Colum L Rev 1015 (cited in note 26); Amram, $32 \mathrm{~J}$ DC Bar Assn 24 (cited in note 23); Comment, Revitalization of the International Judicial Assistance Procedures of the United States: Service of Documents and Taking of Testimony, 62 Mich L Rev 1375 (1964). 
Judicial Procedure. ${ }^{36}$ Given his strong ties to the Commission, Smit's views of the revised statute's application are important to ascertaining the statute's original purpose.

In describing the breadth of the statute's coverage, Smit notes that while the evidence sought under the statute must be for use in a proceeding in a foreign or international tribunal, "[i]t is not necessary ... for the proceeding to be pending at the time the evidence is sought but only that the evidence is eventually to be used in such a proceeding." Smit adds, "[i]n the new version [of the statute], the word 'pending' was eliminated to facilitate the gathering of evidence prior to the institution of litigation abroad. ${ }^{38}$ Smit also describes who may make a request for assistance. The term "interested person" is "intended to include not only litigants before foreign or international tribunals, but also foreign and international officials as well as any other person whether he be designated by foreign law or international convention or merely possess a reasonable interest in obtaining the assistance." Finally, Smit emphasizes that the grant of discretion to the district court judge is of "quintessential importance." $\mathrm{He}$ notes that "[i]n exercising its discretion, the court may not only refuse its assistance, but also grant it upon such terms and conditions as it deems appropriate. The factors that may influence the court's decision include the country, tribunal, or proceedings in which the evidence is to be used; the identity of the litigants in the foreign proceedings; and the persons making the request." ${ }^{\prime 1}$

The Judiciary Committee reports and Professor Smit's commentary thus reveal a uniform and consistent understanding of $\$ 1782$. The drafters of the statute granted judges broad power to assist the collection of evidence by foreign entities, but also vested judges with significant discretionary power to limit discovery. Unfortunately, as the following Section will demonstrate, courts have not adhered to this clear vision.

\footnotetext{
${ }^{36}$ Smit, 65 Colum L Rev at 1015.

Id at 1026.

${ }^{38}$ Id at 1026-27 n 72.

39 Id at 1027.

40 Id at 1029.

41 Id.
} 


\section{JUDICIAL INTERPRETATIONS OF THE STATUTE}

Section 1782 cases arise in three situations: pending criminal prosecutions, pending civil cases, and criminal or other investigations occurring before the commencement of an adjudicative proceeding. Each of these situations raises distinct sets of issues, upon which courts continue to disagree. Courts also have failed to settle on a single, consistent standard applicable to all three classes of requests.

\section{A. Pending Criminal Prosecutions}

When faced with a request for assistance from a foreign court involved in a pending criminal proceeding, U.S. courts have generally granted the request. ${ }^{42}$ The request is usually made by the foreign court itself ${ }^{43}$ or forwarded by the court at the request of the prosecutor. ${ }^{44}$ In either case, courts have been willing to grant the requests because they clearly meet the statutory criteria. ${ }^{45}$

Because a request from a court involved in a pending criminal prosecution fits easily within the statute's terms, judicial inquiries in these cases have examined whether the defendant may assert any legally applicable privilege. ${ }^{46}$ Courts have gen-

12 See In re Letter Rogatory from the Justice Court, District of Montreal, Canada, 523 F2d 562, 565-66 (6th Cir 1975) (granting a request from the Justice Court of Montreal, Canada for the production of the American bank records of a criminal defendant because the amended statute included criminal proceedings); In re Request for Judicial Assistance from the Seoul District Criminal Court, Seoul, Korea, 555 F2d 720, 723 (9th Cir 1977) (granting a request from the Seoul District Criminal Court for the production of the American bank records of a criminal defendant); In the Matter of the Application of Olga Sumar, 123 FRD 467, 471 (S D NY 1988) (granting a request from an Argentine investigating judge on the finding that there was a pending criminal matter in which the evidence would be used).

43 See, for example, Korea, 555 F2d at 722.

4 See, for example, Montreal, 523 F2d at 563.

45 See Korea, 555 F2d at 723 ("Under the statute the only restrictions explicitly stated are that the request be made by a foreign or international tribunal, and that the testimony or material requested be for use in a proceeding in such a tribunal .... There is no question but that such conditions are met here.").

16 Recall the text of $\S 1782$ (a), which states, "A person may not be compelled to give his testimony or statement or to produce a document or other thing in violation of any legally applicable privilege." See also 1964 USCCAN at 3790 (cited in note 27) ("The absence of specific reference to any particular privilege leaves the recognition of the privileges to which the person is entitled to development by case law or separate statute or rule. This seems appropriate since the law in this area is still developing and the desirability of uniform rules of evidence for the district courts is currently under consideration."); Amram, 32 J DC Bar Assn at 31-32 (cited in note 23); Smit, 65 Colum I Rev at 1033-34 (cited in note 26). 
erally considered privileges asserted by defendants on a case-bycase basis. ${ }^{47}$ This category of requests is the least problematic of the three.

\section{B. Pending Civil Cases}

When a litigant in a foreign civil case requests judicial assistance from a U.S. court, a different, and more difficult, set of issues arises. Here, litigants are entitled to request assistance under the statute because they qualify as "interested persons" under $\$ 1782$. In addition, the requested evidence is clearly for use in a "tribunal." However, courts often fear that these requests are actually attempts by the parties to circumvent their own nations' discovery restrictions by taking advantage of more liberal U.S. discovery procedures.

Courts have responded to this concern in several ways. Some require witnesses to submit to an adversarial deposition rather than make an ex parte statement; ${ }^{48}$ others have ordered the parties to seek discovery in the foreign court before requesting U.S. assistance. ${ }^{49}$ The most controversial response to this fear of abuse has been a requirement that any evidence discovered in the United States must also be discoverable in the foreign country. For example, the court in In re the Court of the Commissioner of Patents for the Republic of South Africa denied a request from a party seeking discovery of documents in the United States. ${ }^{50}$ The court found that because the documents would not be discoverable in South Africa, they should not be discoverable in the United States. It noted that to allow discovery would "impede the development of international cooperation among courts. ${ }^{\text {"51 }}$ Similarly, in reviewing a request for assistance from a

47 See Montreal, 523 F2d at 566 (rejecting the foreign criminal defendant's assertion of a right of confrontation under the Sixth Amendment as a "bald assertion of potential harm"); Korea, 555 F2d at 724 (rejecting the defendant's assertion of the California bankcustomer privilege and a right of privacy under the California Constitution). तil).

${ }^{43}$ See Verson Int'l Ltd. $v$ Allied Products Corp., 1987 US Dist LEXIS $8981 * 4$ (N D

49 In the Matter of the Application of Malev Hungarian Airlines, 964 F2d 97, 100 (2d Cir 1992), cert denied as United Technologies International, Inc., $P \& W$ Commercial Engine Business $v$ Malev Hungarian Airlines, $113 \mathrm{~S} \mathrm{Ct} 179$ (1992). In reversing the district court, the Second Circuit struck down this requirement.

so 88 FRD 75, 77 (E D Pa 1980).

51 According to the court:

It is of great concern to this Court that counsel for Opponent have not been able to represent to this Court that the documents and testimony for which Opponents request a discovery order are discoverable under South African law. Indeed, discussions 
Canadian litigant in John Deere Ltd. $v$ Sperry Corp., the Third Circuit took notice of the South Africa court's concern, but permitted the discovery after a finding that the requested evidence would be discoverable in Canada. ${ }^{52}$ Relying on these cases, the Eleventh and First Circuits have gone a step further and mandated a discoverability requirement in every case. ${ }^{53}$

In contrast, the Second Circuit has explicitly refused to adopt a discoverability requirement. In In re Application of Gianoli, the court reasoned that no discoverability requirement appears in the text of the statute and that such a requirement would unjustly restrict the statute's goal of providing wide judicial assistance. ${ }^{54}$ Other courts have criticized the discoverability requirement for imposing an "onerous burden" on U.S. courts to make findings of foreign law and procedure..$^{55}$

with counsel lead this Court to suspect that these materials would not be available through South African procedures. Clearly, this Court should not by its exercise of the discretion allowed it under section 1782 allow litigants to circumvent the restrictions imposed on discovery by foreign tribunals. Few actions could more significantly impede the development of international cooperation among courts than if the courts of the United States operated to give litigants in foreign cases processes of law to which they were not entitled in the appropriate foreign tribunals.

Id.

${ }^{52} 754$ F2d 132, 136 (3d Cir 1985). In John Deere, the Third Circuit was primarily concerned with the admissibility of evidence in the Canadian court. The district court had denied the request partly because the evidence sought would not be admissible at trial. See John Deere Ltd. $v$ Sperry Corp., 100 FRD 712 (E D Pa 1983). The Third Circuit reversed, holding that the ultimate admissibility of the evidence in the foreign court was not a consideration under $\S 1782$. John Deere, 754 F2d at 138.

At least one court has misapplied the John Deere holding that inadmissibility in the foreign country is not grounds to quash a subpoena. See In re Letters Rogatory Issued by the National Court of First Instance in Commercial Matters N. 23 of the Federal Capital of the Argentinean Republic, 144 FRD 272, 277 (E D Pa 1992). That court stated, "In John Deere, the Third Circuit reversed the district court's decision to deny a discovery order based on the district court's conclusion that the material would not be discoverable under Canadian law." Id. But the district court in John Deere focused on the evidence's admissibility, not its discoverability. See John Deere, 754 F2d at 135-36. This distinction is clearly explained in In re Request for Assistance from Ministry of Legal Affairs of Trinidad and Tobago, 848 F2d 1151, 1156 (11th Cir 1988).

${ }^{53}$ See Trinidad and Tobago, 848 F2d at 1156; In re Lo Ka Chun $v$ Lo To, 858 F2d 1564, 1566 (11th Cir 1988); In re Application of Asta Medica, S.A., 981 F2d 1, 6-7 (1st Cir 1992).

s4 3 F3d 54, 59 (2d Cir 1993).

ss See, for example, In re Application of Asta Medica, S.A., 794 F Supp 442, 446 (D Me 1992), rev'd, 981 F2d 1 (1st Cir 1992). 
C. Criminal and Other Investigations Taking Place Before the Commencement of an Adjudicative Proceeding

The most challenging $\S 1782$ cases involve requests for assistance from foreign officials who are investigating alleged crimes or violations but have not begun adjudicative proceedings. Broadly speaking, two different tests have developed for deciding whether to grant these requests. Under the first test, courts ask whether the requesting party qualifies as a "tribunal." Under the second test, courts ask about the likelihood of an adjudicative proceeding.

Early $§ 1782$ cases evaluated requests by asking whether the requestor qualifies as a tribunal..$^{56}$ For example, in In re Letters Rogatory Issued by the Director of Inspection of the Government of India, an Indian income tax officer sought to obtain American bank records and depose corporate and bank officers to determine income tax assessments for an Indian citizen. ${ }^{57}$ Judge Friendly denied the request, holding that the Indian tax officer was not a "tribunal" as the word is used in the statute. ${ }^{58}$ In Judge Friendly's view, a "tribunal" is objective and has no institutional interest in a particular result in a case..$^{59}$ As an example of a tribunal, Judge Friendly described a French juge d'instruction, who investigates a crime but represents neither the police nor the prosecutor and aims only to ensure that justice is done. ${ }^{60} \mathrm{In}$ contrast, the Indian tax officer, like a United States Internal Revenue agent, has a decidedly biased position. Under the India standard, therefore, a request for assistance will be granted only if it emanates from an impartial, adjudicative body; requests from institutionally biased parties will not be honored. ${ }^{61}$

${ }^{56}$ See In re Letters of Request to Examine Witnesses from the Court of Queen's Bench for Manitoba, Canada, 59 FRD 625 (N D Cal 1973) (denying a request from the Manitoba Commission of Inquiry because the Commission only reported to the executive or legislative branch of the government and did not perform the adjudicative functions of a tribunal).

67385 F2d 1017 (2d Cir 1967).

s8 Id at 1022.

69 Id at 1020.

${ }^{60}$ Id, citing A.E. Anton, L'Instruction Criminelle, 9 Am J Comp L 441, 443 (1960).

61 The India standard was reaffirmed in 1980 by Fonseca $v$ Blumenthal, 620 F2d 322, 323 (2d Cir 1980), and was the basis of the opinion in In re Letter of Request for Judicial Assistance from the Tribunal Civil de Port-au-Prince, Republic of Haiti, 669 F Supp 403 (S D Fla 1987) (finding a Haitian juge d'instruction to be a quasi-judicial entity that falls within $\S 1782$ ). But see note 67 and text accompanying notes 91-92.

The request for assistance in Fonseca sought a suitcase containing $\$ 250,000$ in cash that was allegedly checked on a flight from Bogotá to Lima, but was misdirected by the airline to JFK Airport in New York. The owner of the suitcase sought its return, but the 
A second class of $\S 1782$ cases focuses on the likelihood of an adjudicative proceeding. In In re Request for Assistance from Ministry of Legal Affairs of Trinidad and Tobago, the Eleventh Circuit granted a request from a non-adjudicative body and outlined a new standard for reviewing such requests. ${ }^{62}$ Trinidad and Tobago concerned a request for assistance in a criminal investigation from that country's Minister of Legal Affairs. The court framed the inquiry as "whether section 1782 requires that a proceeding be pending before a federal court may grant judicial assistance to a foreign official." ${ }^{263}$ Focusing on the 1964 amendments, the court reasoned:

Congress' elimination of the word "pending" almost compels us to conclude ... that a pending proceeding is not absolutely necessary .... . [T] he determination to grant assistance turns not on whether the proceeding is pending but on whether the requested evidence will likely be of use in a judicial proceeding. ${ }^{64}$

The court concluded that "[t]he district judge should satisfy himself that a proceeding is very likely to occur"; finding that a proceeding was "imminent," the court granted the request. ${ }^{65}$

In subsequent cases, courts followed Trinidad and Tobago by holding that $\S 1782$ does not require a pending adjudicative proceeding, and by inquiring as to the likelihood of an adjudicative proceeding. In In re Letter of Request from the Crown Prosecution Service of the United Kingdom, then-Judge Ruth Bader Ginsburg held that "[t]he judicial proceeding for which assistance is sought ... need not be pending at the time of the request for assistance; it suffices that the proceeding in the foreign tribunal and its contours be in reasonable contemplation when the request is made." ${ }^{36}$ In In re Request for International Judicial Assis-

Superintendent of Exchange Control of Colombia also made a request that the suitcase and its contents be delivered to him for examination. Perhaps not surprisingly, the request was denied. See Fonseca, 620 F2d at 322-23.

62848 F2d 1151 (11th Cir 1988).

63 Id at 1152.

of Id at 1155 .

as Id at 1156. See also In re Letters Rogatory from the Tokyo District, Tokyo, Japan, 539 F2d 1216 (9th Cir 1976). There, the Ninth Circuit permitted a grant of assistance to a Tokyo Public Prosecutor. The court ignored the fact that the prosecutor was not an impartial, adjudicative body and instead granted the request because it was related to a possible judicial or quasi-judicial proceeding. Id at 1217-18.

66870 F2d 686, 687 (DC Cir 1989). The case concerned an investigation by British authorities of an allegedly illegal stock manipulation scheme by one of the officers of 
tance (Letter Rogatory) for the Federative Republic of Brazil, ${ }^{67}$ the Second Circuit imposed a stricter version than Trinidad and Tobago: "Though we will not insist that proceedings be 'pending,' we think it prudent ... to require that adjudicative proceedings be imminent-very likely to occur and very soon to occur. ${ }^{n 88} \mathrm{Bra}$ $z i l$ has been criticized because its "imminence" standard appears stricter than the Trinidad and Tobago and Crown Prosecution Service tests, which require only that an adjudicative proceeding be "likely" or "within reasonable contemplation." However, under any of these standards, the grant of assistance depends upon a prediction that an adjudicative proceeding is likely.

The tension between courts that ask whether the requesting party qualifies as a tribunal and courts that ask whether a proceeding is imminent was demonstrated in In re Letter of Request from the Government of France. ${ }^{70}$ The France court received letters rogatory from a French juge d'instruction who, as described above, investigates a crime but has no institutional interest in the outcome of a case. ${ }^{71}$ Under Judge Friendly's India standard, the request would be granted because the juge d'instruction is an impartial, adjudicative office. But under the Brazil standard, the request would be granted only if an adjudicative proceeding was imminent. In this case, the imminence of a proceeding was uncertain precisely because of the juge d'instruction's historic objectivity. $^{72}$ While a straightforward reading of Brazil would seem to require that the request be denied, the France court stated that "we cannot believe that our Circuit in In re Brazil intended to preclude the French juges from the use of the statute" and concluded that the juge d'instruction's investigation constituted a

Guinness, PLC in its takeover of the Distillers Company.

67936 F2d 702 (2d Cir 1991). The case concerned a Brazilian investigating judge's request for assistance in obtaining evidence from a New York bank. In Brazil (and in other South American countries, notably Argentina), criminal procedure is divided into pre- and post-accusatory phases called somario and plenario, respectively. In the somario phase, the investigating judge gathers evidence with the assistance of the police. In the plenario phase, the object of the investigation is indicted and becomes a party. See Robert Redden, ed, Modern Legal Systems Cyclopedia $\S 1.3(D)(2)$ at 10.20.39 (Hein, 1991). Thus, the investigating or somario judge performs no adjudicative function. See Brazil, $936 \mathrm{~F} 2 \mathrm{~d}$ at 705. See also Sumar, 123 FRD at 470-71 (mistakenly finding that the somario judge performs an adjudicative role).

6s 936 F2d at 706.

69 See Note, In re Request for Judicial Assistance from the Federative Republic of Brazil: A Blow to International Judicial Assistance, 41 Cath U L Rev 545, 566-74 (1992).

70139 FRD 588 (S D NY 1991).

71 See text accompanying note 60 .

72 See France, 139 FRD at 590-91. 
"formal, ongoing, adjudicatory, judicial proceeding" that allowed the court to grant the request. ${ }^{73}$

\section{A RETURN TO THE JUDGE'S DISCRETION}

Section 1782 requests from courts involved in pending criminal prosecutions have created little controversy because they fall clearly within the ambit of the statute. ${ }^{74}$ Cases involving $\$ 1782$ requests from private litigants have produced disagreement over whether a discoverability requirement-which insists that discovery in the United States be limited to evidence that would be discoverable in the foreign jurisdiction-is warranted. ${ }^{75}$ Cases involving $\S 1782$ requests from investigating officials prior to the commencement of adjudicative proceedings have led to a dispute over the proper test for granting or denying assistance. ${ }^{76}$ After discussing the jurisprudence of the cases in the latter two categories, this Comment proposes a three-part discretionary test to cover all three categories of $\S 1782$ requests. This test adheres to the plain language of the statute and is consistent with both the legislative intent and policies underlying the statute.

\section{A. Problems with Judicial Interpretations of $\S 1782$}

\section{Pending civil cases.}

For $\S 1782$ requests from litigants in pending civil cases, the most controversial issue is whether the statute mandates a discoverability requirement. The Eleventh and First Circuits have made discoverability a prerequisite to any grant of assistance. ${ }^{77}$ The Second Circuit, on the other hand, has refused to impose such a requirement. ${ }^{78}$ Courts that have imposed a discoverability requirement have done so out of fear that litigants will otherwise exploit $\S 1782$ to circumvent discovery restrictions in the litigant's home country. Because the discovery requirement effectively prevents this abuse, judges should have discretion to use the requirement when, in their view, such abuse is likely.

${ }^{73}$ Id at 591.

74 See text accompanying notes $42-47$.

75 See text accompanying notes $48-55$.

${ }^{76}$ See text accompanying notes 56-73.

7 See text accompanying notes 50-53. The Eastern District of Pennsylvania in South Africa and the Third Circuit in John Deere both discussed a discoverability requirement but did not make it a requirement for every case. See South Africa, 88 FRD at 77; Gianoli, 3 F3d at 61 n 3; John Deere, 754 F2d at 136.

${ }^{78}$ See text accompanying notes 54-55; Gianoli, 3 F3d at 60-61. 
However, despite concerns about circumvention, courts should not impose a discoverability requirement in every case. As explained in Gianoli, this requirement is not explicit in the statute and frustrates the statute's objective of providing broad assistance. ${ }^{79}$ Furthermore, concern about circumvention is only valid when one litigant seeks discovery from the other. ${ }^{80}$ In other circumstances, a discovery requirement may be improper or irrelevant. For example, if the requesting party is a foreign judge, imposing a discoverability requirement might be viewed as an affront to the foreign nation's sovereignty and an insult to the foreign judge. ${ }^{81}$ Furthermore, in cases involving criminal investigations or prosecutions, civil discovery procedures simply do not apply. ${ }^{82}$ Although district courts should be aware of the discoverability requirement as a useful tool for preventing abuse of the statute in one situation, ${ }^{83}$ mandating such a requirement for all $\S 1782$ cases is unwarranted.

2. Investigations taking place before the commencement of an adjudicative proceeding.

The cases in which a foreign investigator makes a request for assistance prior to initiating an adjudicative proceeding present the greatest difficulty. As described above, courts have developed two approaches to evaluating this category of $\S 1782$ requests: some ask whether the requesting party qualifies as a tribunal, while others focus on whether an adjudicative proceeding appears likely or imminent. ${ }^{84}$ Neither approach is satisfactory.

Under the India test, a request can only be granted if the requestor qualifies as a "tribunal," defined by Judge Friendly as an objective body exercising adjudicative powers. ${ }^{85}$ Section 1782 ,

793 F3d at 59-60.

Bo See Stahr, 30 Va J Intl L at 613 (cited in note 12).

81 In Germany, for example, the court itself obtains the evidence it deems necessary. See John H. Langbein, The German Advantage in Civil Procedure, 52 U Chi L Rev 823, 827-29 (1985). A United States court ruling on the discoverability of evidence requested by a German court might impinge on the powers of the German judge.

82 The Trinidad court can therefore be criticized for imposing a discoverability requirement in a criminal case. See Stahr, $30 \mathrm{Va}$ Intl L J at 610-11.

"[D]istrict judges may well find that in appropriate cases a determination of discoverability under the laws of the foreign jurisdiction is a useful tool in their exercise of discretion under section 1782." Gianoli, 3 F3d at 60.

S4 See text accompanying notes 56-73.

${ }_{85}$ India, 385 F2d at 1021. See also Brazil, 936 F2d at 705. Stahr has criticized Judge Friendly's definition of tribunal as unduly narrow. Stahr, $30 \mathrm{Va} \mathrm{J}$ Intl L at $617 \mathrm{n} 123$ (arguing that defining a tribunal as an "adjudicatory" authority is too narrow; tribunal 
however, explicitly allows requests both from tribunals and interested persons. Following the familiar canon of interpretation that each word of a statute be given effect, ${ }^{86}$ we must assume that Congress did not mean for the term "interested person" to be redundant or superfluous. It seems unlikely that the statute would allow a request from an interested person but then deny it if the interested person is not a tribunal (interested persons are rarely tribunals). For example, a party to a lawsuit or a prosecutor would certainly qualify as an interested person but would be denied discovery under the India test because the party or prosecutor is not a tribunal. The India standard thus ignores the clear language of $\S 1782$.

A second problem with the India standard is that if tribunals only hear pending cases, then limiting $\S 1782$ requests to tribunals would, as a practical matter, require a pending adjudicative proceeding before a judge can grant a $\$ 1782$ request. ${ }^{87}$ Such a pendency requirement conflicts with apparent congressional intent. As Trinidad and Tobago and other authorities have noted, the word "pending" was removed from the statute in the 1964 amendments, and thus a pending adjudicative proceeding is not necessary to grant assistance. ${ }^{88}$ The Brazil court and other authorities, however, have suggested that the removal of the word "pending" may have been accidental, because the legislative history fails to discuss the removal of the word. Indeed, the Senate Judiciary Committee report states that assistance should be granted "when proceedings are pending before investigating magistrates."

often means something less formal than a court or judicial authority). But see Webster's Third New International Dictionary 2441 (1986) (a tribunal is "something that decides or judges"); United States $v$ Meyers, 75 F Supp 486, 487 (D DC 1948) ("The court has considerable doubt whether a Congressional committee is a tribunal, because the word 'tribunal' implies an officer or body having authority to adjudicate matters."). Judge Friendly has also been criticized for including the French juge d'instruction within the definition of "tribunal." See Comment, Judicial Assistance for the Foreign "Tribunal," 1968 Duke L J 981, 988-91 (arguing that the juge d'instruction's function is more prosecutorial than adjudicative).

${ }^{86}$ See Norman J. Singer, 2A Statutes and Statutory Construction $\S 46.06$ at 119 (Clark Boardman, 5th ed 1992).

${ }_{87}$ See India, 385 F2d at 1020-22. This conclusion is not explicitly stated but follows logically from the India test, which only grants assistance to tribunals.

88 Trinidad and Tobago, 848 F2d at 1155; Crown Prosecution Service, 870 F2d at 690; Brazil, 936 F2d at 705-06.

89 1964 USCCAN at 3788, quoted in Brazil, 936 F2d at 705 (emphasis added). See also Comment, Much Ado About 1782: A Look at Recent Problems with Discovery in the United States for Use in Foreign Litigation Under 28 U.S.C. \$ 1782, 20 U Miami Int-Am I Rev 429, 438-40 (1989). 
This argument ignores significant evidence that the removal was in fact quite intentional. First, the commentary by Professor Smit, who played an important role in drafting the statutory amendment, ${ }^{90}$ notes that "[t]he word 'pending' was eliminated to facilitate the gathering of evidence prior to the institution of litigation abroad." ${ }^{\prime 11}$ Second, the statute, as a whole, was intended to have broad application and provide wide judicial assistance. This policy dictates removing-not adding-obstacles such as the pendency requirement. Finally, the fact that $\S 1782$ 's legislative history indicates that judges are to provide assistance to investigating magistrates as well as tribunals strongly suggests that imposing a "pending adjudicative proceeding" requirement is inappropriate. A significant length of time can pass between the initiation of an investigation and the commencement of an adjudicative proceeding based on the findings of that investigation. Section 1782 would provide little assistance to investigating magistrates if American courts could not provide discovery until an adjudicative proceeding was finally pending.

The Trinidad and Tobago line of cases is also problematic. These cases hold that an adjudicative proceeding need not be pending, but rather must be likely, within reasonable contemplation, or imminent. ${ }^{22}$ But neither the statute nor common sense compels this connection between a grant of assistance and the likelihood of an adjudicative proceeding. First, the statute nowhere states that courts can only grant a request if an adjudicative proceeding is likely. Second, granting or denying a request based on the likelihood of an adjudicative proceeding requires the U.S. judge to assess whether a given adjudicative proceeding in a foreign nation is likely. This is not only difficult, but often impossible. Consider the request of an investigating judge in Brazil or Argentina. Because the investigating judge merely gathers evidence and does not decide whether to join the defendant in a prosecution, ${ }^{93}$ the likelihood of an adjudicative proceeding is necessarily uncertain while the matter is in the investigating judge's hands. In fact, the entire role of the investigating judge is to help decide the likelihood of an adjudicative proceeding. Asking a U.S. court to make that determination before the evidence is collected is simply inappropriate. Even in less clear-cut cases, assistance

90 See text accompanying note 36 .

91 Smit, 65 Colum L Rev at 1026-27 n 72 (cited in note 26).

${ }^{92}$ See text accompanying notes $62-69$.

${ }^{93}$ See text accompanying notes 59-60. 
to any investigating official serves only to aid that official in deciding whether to adjudicate the claim. Requiring the district court judge to determine the likelihood of an adjudicative proceeding before the foreign official makes that determination is premature and inexpedient.

\section{B. The Merits of Judicial Discretion}

The inconsistencies and controversies in $\$ 1782$ jurisprudence stem from judicially-imposed requirements having no basis in the statutory text. The statute neither mandates foreign discoverability nor requires that an adjudicative proceeding be likely or imminent. By creating such additional requirements, courts have disregarded the plain language of the statute and its emphasis on judicial discretion, instead introducing inflexible and ineffective rules.

Courts should dispense with these ill-fitting and unwarranted rules and instead evaluate $\$ 1782$ requests using a three-part test that emphasizes the judge's discretion. The test proposed here would be useful to judges reviewing all types of requests for assistance. The district court judge should first ask whether the requestor is a tribunal or an interested person, and then ask if the requested evidence is likely to be of use in an adjudicative proceeding. If both answers are affirmative, then the judge should use the discretion allowed by the statute to grant or deny the request, or limit it in any reasonable way that ensures the administration of justice.

This test is derived directly from the statute's language and is therefore consistent with a textualist approach to statutory interpretation. ${ }^{94}$ Since the understanding of $\S 1782$ that emerges from this textualist approach is fully supported by the statute's legislative history, the proposed test is also consistent with an intentionalist approach to statutory interpretation..$^{95}$ In particu-

94 Support for a textualist approach can be found in Immigration and Naturalization Service v Cardoza-Fonseca, 480 US 421, 452-55 (1987) (Scalia concurring); Frank H. Easterbrook, The Role of Original Intent in Statutory Construction, 11 Harv J L \& Pub Pol 59, 59-60 (1988). As Holmes stated, "[w]e do not inquire what the legislature meant; we ask only what the statute means." Oliver Wendell Holmes, Jr., The Theory of Legal Interpretation, 12 Harv L Rev 417, 419 (1898-99). See also Justice Frankfurter's "threefold imperative to law students: (1) read the statute; (2) read the statute; (3) read the statute!" Henry J. Friendly, Benchmarks 202 (Chicago, 1967).

${ }_{95}$ Support for an intentionalist approach can be found in W. David Slawson, Legislative History and the Need to Bring Statutory Interpretation Under the Rule of Law, 44 Stan L Rev 383 (1992); Earl M. Maltz, Statutory Interpretation and Legislative Power: The Case for a Modified Intentionalist Approach, 63 Tulane L Rev 1 (1988); Richard S. Kay, 
lar, the test accords with the views of the specially appointed commission that wrote the version of $\S 1782$ passed unanimously by both houses. ${ }^{96}$ Finally, a best answer or "attribution of purpose" approach, which asks what is the most principled or most reasonable result under the statute, also supports the three-part test. $^{97}$

\section{Is the requestor a tribunal or an interested person?}

This first step of the discretionary test ensures compliance with the literal terms of the statute. ${ }^{98}$ As discussed above, the term "tribunal" refers to an objective body with adjudicative powers. ${ }^{99}$ The term "interested person" is much broader. Taken at its plain or literal meaning; the term applies to any person possessing a reasonable interest in the matter, including foreign or international tribunals, litigants, and foreign or international officials. This interpretation is supported by the legislative history of $\S 1782^{100}$ and commentary. ${ }^{101}$ Furthermore, a broad definition of the term "interested person" makes sense under an attribution-of-purpose analysis. Given the statute's expressed goal of allowing wide judicial assistance for foreign discovery, a broad definition of "interested person" is surely desirable.

Under this definition, virtually all requests come from "interested persons." The step becomes a mere formality. Yet the language of the statute compels this result. Congress made a policy

Adherence to the Original Intentions in Constitutional Adjudication: Three Objections and Responses, 82 Nw U L Rev 226 (1988).

${ }^{96}$ See text accompanying note 26 . Reliance on legislative intent has been criticized on the grounds that because legislatures have many members, they do not have a single, unified "intent." See Frank H. Easterbrook, Statutes' Domains, 50 U Chi L Rev 533, 547 (1983). See also Kenneth A. Shepsle, Congress is a "They," not an "It": Legislative Intent as Oxymoron, 12 Intl Rev L \& Econ 239, 249 (1992). However, this criticism carries less weight in the context of $\S 1782$, because the statute was enacted by a unanimous vote in both houses.

${ }_{97}$ See Henry M. Hart, Jr. and Albert M. Sacks, The Legal Process: Basic Problems in the Making and Application of Law ch 7, 1144 (Cambridge, tentative ed 1958).

${ }_{98}$ Section 1782 states, "The order may be made pursuant to a letter rogatory issued, or request made, by a foreign or international tribunal or upon the application of any interested person ...." (emphasis added).

99 See text accompanying note 85 .

100 See text accompanying note 32. The legislative history makes clear that foreign tribunals, international tribunals, litigants and investigating magistrates may all be requesting parties.

101 Smit states that "interested persons" include litigants, foreign and international officials, "as well as any other person whether he be designated by foreign law or international convention or merely possess a reasonable interest in obtaining the assistance." Smit, 65 Colum L Rev at 1027 (cited in note 26). 
choice that the identity of the requesting party should not serve as an absolute bar to a grant of judicial assistance. Instead, the identity of the requesting party becomes relevant in the discretionary step, where the judge can tailor the response to the specific circumstances of the case.

2. Is the requested evidence likely to be of use in an adjudicative proceeding?

This step requires an interpretation of the statute's ambiguous requirement that the evidence be "for use in a proceeding in a foreign or international tribunal." Even if one simplifies the phrase to mean "for use in an adjudicative proceeding," it still permits two constructions. On one hand, the phrase might require that the evidence be for use in an adjudicative proceeding that is presently occurring, in other words, a pending adjudicative proceeding. On the other hand, the phrase might be less restrictive, requiring only that the evidence could eventually be used in an adjudicative proceeding. ${ }^{102}$

The first construction is untenable because it imposes a pendency requirement that the statute does not require. ${ }^{103}$ The second construction, asking whether the evidence could eventually be used in an adjudicative proceeding, avoids this problem and is therefore more consistent with the statute's text and legislative history. ${ }^{104}$ The second construction is also preferable because it is supported by the legislative intent to provide assistance to interested persons in addition to tribunals. ${ }^{105}$ Finally, under the attribution-of-purpose approach, the second construction more closely reflects the policy of providing wide judicial assistance.

Like the first step, this second step is also a low hurdle. It correctly excludes requests for evidence that will never be used in an adjudicative proceeding. ${ }^{106}$ Again, specific tailoring of admitted requests is left to the discretionary step.

102 See Comment, Judicial Assistance: Obtaining Evidence in the United States, Under 28 U.S.C. \$ 1782, for Use in a Foreign or International Tribunal, 5 BC Intl \& Comp L Rev $175,186-87$ (1982) (discussing these two possible constructions).

${ }_{103}$ See text accompanying notes 87-93.

104 The basis for this step is Trinidad and Tobago, which stated, "the determination to grant assistance turns not on whether the proceeding is pending but on whether the requested evidence will likely be of use in a judicial proceeding." 848 F2d at 1155.

${ }_{105}$ See text accompanying notes 100-02.

${ }_{106}$ See In re Letters of Request to Examine Witnesses from the Court of Queen's Bench for Manitoba, Canada, 59 FRD 625, 628-29 (N D Cal 1973) (Because the Canadian Commission of Inquiry only reported to the executive or legislative branches of the government, the evidence requested was not for use in an adjudicative proceeding.). 
3. Using discretion to limit the request as necessary.

After ascertaining whether the request complies with the two statutory requirements, the judge should then use his or her discretion to honor, limit, or deny the request. Both the statutory text, which grants discretionary power to the district court judge, and the expressed legislative intent support this criterion.

Factors that the judge may consider include "the character of the proceedings" and "the nature and attitudes of the government ... from which the request emanates," or "the nature of the [international] tribunal." 107 In considering the nature of the tribunal or the character of the proceedings in which the dispute will ultimately be heard, the judge can give weight to the type of institution that will adjudicate the matter. In considering the character of the proceedings, the judge may differentiate between requests from courts, parties, or investigators. ${ }^{108}$ The judge may deny the request if the judge suspects the inquiry is an unnecessary invasion of privacy, a fishing expedition, or a vehicle for harassment. ${ }^{109}$ Instead of outright denial, the judge may impose restrictions on the request, such as a discovery requirement, in order to prevent abuse of the statute. The judge should also consider whether the defendant can assert any privileges under foreign, federal, or state law. ${ }^{110}$

Some considerations, however, are invalid. Courts should not consider the admissibility of the evidence in the foreign court, as admissibility is generally a technical question beyond the threshold issue of discoverability. ${ }^{111}$ Courts should not consider how the courts of the requesting nation treat letters rogatory from the United States because the statute provides for unilateral assistance and does not depend on reciprocal agreements. ${ }^{122}$ For similar reasons, the Second Circuit struck down a requirement that the parties first exhaust available discovery in the foreign court before requesting United States assistance. ${ }^{113}$

1071964 USCCAN at 3788 (cited in note 27).

${ }^{208}$ See Smit, 65 Colum L Rev at $1029 \mathrm{n} 87$ (cited in note 26) ("For example, a request emanating from a foreign court may command greater respect than a request submitted by an individual litigant.").

${ }_{109}$ See Trinidad and Tobago, 848 F2d at 1156.

110 See text accompanying notes $46-47$.

11 See John Deere, 754 F2d at 136; Korea, 555 F2d at 723; Tokyo, 539 F2d at 1219.

112 See John Deere, 754 F2d at 135; Société Nationale Industrielle Aérospatiale v United States District Court for the Southern District of Iowa, 482 US 522, 529-30 (1987) (The statute grants "foreign litigants, without any requirement of reciprocity, special assistance in obtaining evidence in the United States."); Montreal, 523 F2d at 565.

${ }^{113}$ See Malev Hungarian Airlines, 964 F2d at 100. 
The discretionary test may be criticized for giving too much discretion to the district court judge, allowing random and inconsistent grants or denials of assistance based on the judge's intuitions. However, $\S 1782$ assistance is not unlimited. ${ }^{1{ }^{14}}$ Instead, the statute grants the district court judge discretion to consider the most pertinent factors: who is the requestor, what evidence is requested, and what is the burden on the party being ordered to produce the evidence. If the judge is skeptical of the requesting party's authority, suspects a fishing expedition, or finds that ordering the production of evidence would unduly infringe a person's privacy rights, the judge may deny the request. By avoiding rigid or mechanical rules and emphasizing discretion, this test allows a judge to grant appropriate requests and deny inappropriate ones. The grant of discretion is eminently clear in the statute, legislative history, and commentary. The statute was designed and enacted with discretion in mind, and courts should not abdicate this responsibility.

Another possible criticism is that international norms and circumstances have changed so much that the grant of broad discretionary power is no longer appropriate. ${ }^{115}$ However, the greater complexity of today's international legal framework only strengthens the argument for a grant of broad discretionary power. Allowing the judge to consider the specific circumstances of each case will best permit the judge to reach the proper result when circumstances do change. Imposing strict requirements only hinders the judge's ability to reach the right result.

A few examples demonstrate the benefits of the discretionary test. For example, on the facts of India, ${ }^{116}$ rather than deny assistance because the Indian tax officer is not a tribunal, the judge would find that the Indian tax officer is an interested party and that the evidence requested could eventually be used in an adjudicative proceeding. Then, in the discretionary step, the judge could decide whether to grant assistance by weighing the position of the Indian tax officer, the tax officer's adjudicative powers, the type of evidence requested, the nature of the proceeding, and the burden on the targeted party to produce documents or give testi-

114 See, for example, India, 385 F2d at 1020 (Congress "did not go to the full extent of authorizing a district court to execute letters rogatory whenever requested by a foreign country or a party ....").

115 See, for example, William N. Eskridge, Jr., Dynamic Statutory Interpretation, 135 U Pa L Rev 1479 (1987) (Statutes should 'be interpreted 'dynamically,' that is, in light of their present societal, political, and legal context.").

116385 F2d 1017. 
mony. This inquiry would also allow the court to balance the invasion of privacy against the seriousness of the crime charged. On the facts of $\mathrm{Brazil},{ }^{117}$ the judge would not need to entertain arguments about the imminence of an adjudicative proceeding. Instead, the judge would find that the Brazilian investigating judge is an interested person, that the evidence requested could eventually be used in an adjudicative proceeding, and then would consider the discretionary factors outlined above.

The three-part discretionary test is preferable to other tests for several reasons. First, by meeting all the statutory requirements without introducing additional criteria, the discretionary test adheres to the plain language of the statute. In addition, by emphasizing the discretion granted to the district court judge, the test best fulfills the statutory policy of providing broad assistance. It complies with $\S 1782$ 's mandatory requirements and allows discretion where $\S 1782$ so provides. It does not ignore requests from interested persons, as the India test does. It does not ask the district court judge to determine the likelihood of an adjudicative proceeding before the foreign official makes that determination, as the Trinidad test does. By adhering to the statutory text, the test provides a means for courts to adopt a uniform interpretation of $\S 1782$.

\section{CONCLUSION}

Controversies surrounding the interpretation of $\S 1782$ arise in three situations: pending criminal prosecutions, civil litigation in which one of the parties requests assistance, and requests by investigating officials before the commencement of adjudicative proceedings. In each situation, the judicial departure from the statute's plain language has resulted in inconsistent treatment of virtually identical $\S 1782$ requests. To resolve these inconsistencies, courts should apply a three-part discretionary test. Courts should ask first whether the requestor is a tribunal or an interested party, and second whether the requested evidence is likely to be of use in an adjudicative proceeding. Third, judges should use their discretionary power to weigh relevant factors in deciding whether to grant, tailor, or deny the request for assistance. This test adheres to the language and legislative history of $\$ 1782$. It provides the best solution from the policy perspective of granting wide assistance, and allows judges to successfully ad- 
dress requests concerning all factual situations. As disputes across international boundaries become more numerous, a consistent and correct interpretation of $\$ 1782$ will allow more fruitful application of the statute. 
- 